\title{
1994: Science enters the post-Cold War era
}

The past year has seen continuing transition on the global stage. The storming of the Russian Parliament in October indicated that, whatever the future of the former communist countries of Eastern Europe, a return to the rigid East-West confrontations of the Cold War is unlikely. The successful termination of negotiations on the General Agreement on Trade and Tariffs has established the codes of conduct under which the global wars of the immediate future - those over access to markets - will be fought.

In the following pages, our correspondents around the world report on the impact these trends are already having on the way research is conducted. The most obvious, namely the reduced need for heavy spending on military research, is perhaps the least significant. There has been little evidence that funds freed in this way are being directly transferred to civilian research; indeed it would be surprising to see the so-called 'peace dividend' surface in this simplistic way.

More significant has been the need to fill the role previously played by government support of military research in maintaining the health of the science base, particularly in countries such as the United States and the former Soviet Union. It is this, together with a shift in concern from military to economic security, that has helped to determine the new world scientific order emerging in countries of both East and West, North and South.

What are the main characteristics of this new order? First, that governments both conservative (as in Britain, France and Germany) and liberal (as in the United
States, Canada and Australia) feel a new responsibility to back research policies designed to boost 'strategic' civilian technologies given the market's inability to address issues of national security.

Second, that in a world where the ability to prosper depends on the quality

\section{IMAGE UNAVAILABLE FOR COPYRIGHT REASONS}

Point of no return: Muscovites watch the attack on the Russian parliament.

of technical skills as judged by the market-place, the criteria used to evaluate research projects are increasingly those accepted by the international scientific community, rather than those that meet local self-interest. Hence the growing willingness of countries such as Japan, France and Italy, previously suspicious of the judgement of outsiders, to open their research systems to external review.

\section{US looks cautiously to Clinton for leadership into new territory}

Washington. The opening year of President Bill Clinton's administration cut both ways for science. The scientific community was able to applaud the appointment of a string of its respected members to posts in the administration. But many also saw the closure of the Superconducting Super Collider (SSC) as an ominous turning point in Washington's approach to science funding.

This year will see how far these hopes and fears - are justified. In particular, it will demonstrate the impact of what was perhaps 1993's most profound development in science policy, namely the creation of a National Science and Technology Council. This 'science cabinet' will be chaired by Clinton himself, and will oversee the federal government's entire \$76-billion research budget.
The appointments of Harold Varmus, the Nobel prize-winning molecular biologist, as director of the National Institutes of Health (NIH), and of the respected physicist Neal Lane to head the National Science Foundation (NSF), reassured the scientific community that the case for basic research would be strongly argued in top political circles.

Such support is likely to become increasingly necessary in a political climate that requires every dollar spent on research to be fully justified in terms of some social outcome, whether it is greater industrial competitiveness or a lower infant mortality rate.

No such justification was forthcoming for the ill-fated SSC. Policy makers are looking to the new council to provide a clear direction for science, to replace the fog in which the Texan atom smasher was lost.
Third, scientific projects whose motivation lay partly in national prestige itself a valuable currency during the Cold War - have lost much of their lustre. The Superconducting Super Collider (SSC) in the United States is one such casualty. A similar fate could soon meet NASA's planned 'international' space station, while France is under pressure to reduce funding for large projects in fields such as space and nuclear energy. Science as a political spectacle has lost its bite.

As the reports below indicate, the postCold War era has brought new promises for science, including a renewed political commitment (valuable when the welfare state is under attack) and a determination to address shortcomings in science and engineering education. But it has also brought new threats, from the marginalization of research whose potential contribution to wealth or well-being cannot be demonstrated, to the shrivelling of support for research teams (for example in the former communist states or in the newly industrialized nations) illequipped to survive the harsh winds of international competition.

Scientists may have less to fear than they did at the beginning of 1993; the promise of renewed economic growth can only be good news for those whose funding prospects depend directly on the health of the economy that supports them. But, with research budgets being frozen virtually everywhere, and pressure increasing to evaluate all research projects in terms of competitive advantage, 1994 does not yet promise much cause for celebration.

Varmus, for one, describes it as "very useful and potentially very important"; Bruce Alberts, president of the National Academy of Sciences, says the council will work if Clinton wants it to do so.

The will is certainly there. At a recent White House reception for Nobel laureates, Clinton and his wife Hillary seemed to impress their guests. Varmus says they were "informed and enthusiastic" on science policy matters, and predicts the president will chair the council with gusto.

Guided by Jack Gibbons, the president's science advisor, the administration appears to have accepted the importance of fundamental science. But Congress is likely to continue to press strongly for research that meets "strategic" goals. And the first to come in for close scrutiny will be the NSF.

In a few weeks, Lane is due to appear before the Senate appropriations subcommittee chaired by Barbara Mikulski (Democrat, Maryland) to explain how he plans to make sure that 60 per cent of NSF's work 